\title{
Transatlantica
}

Revue d'études américaines. American Studies Journal

Hors-série | 2021

Numéro anniversaire : 20 ans de la revue

\section{An Interview with Olaf Stieglitz}

\section{Guillaume Marche and Olaf Stieglitz}

\section{(2) OpenEdition}

\section{Journals}

\section{Electronic version}

URL: https://journals.openedition.org/transatlantica/17530

DOI: 10.4000/transatlantica. 17530

ISSN: $1765-2766$

\section{Publisher}

Association française d'Etudes Américaines (AFEA)

\section{Electronic reference}

Guillaume Marche and Olaf Stieglitz, "An Interview with Olaf Stieglitz", Transatlantica [Online], Horssérie | 2021, Online since 01 October 2021, connection on 11 October 2021. URL: http:// journals.openedition.org/transatlantica/17530 ; DOI: https://doi.org/10.4000/transatlantica.17530

This text was automatically generated on 11 October 2021.

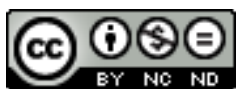

Transatlantica - Revue d'études américaines est mise à disposition selon les termes de la licence Creative Commons Attribution - Pas d'Utilisation Commerciale - Pas de Modification 4.0 International. 


\section{An Interview with Olaf Stieglitz}

\section{Guillaume Marche and Olaf Stieglitz}

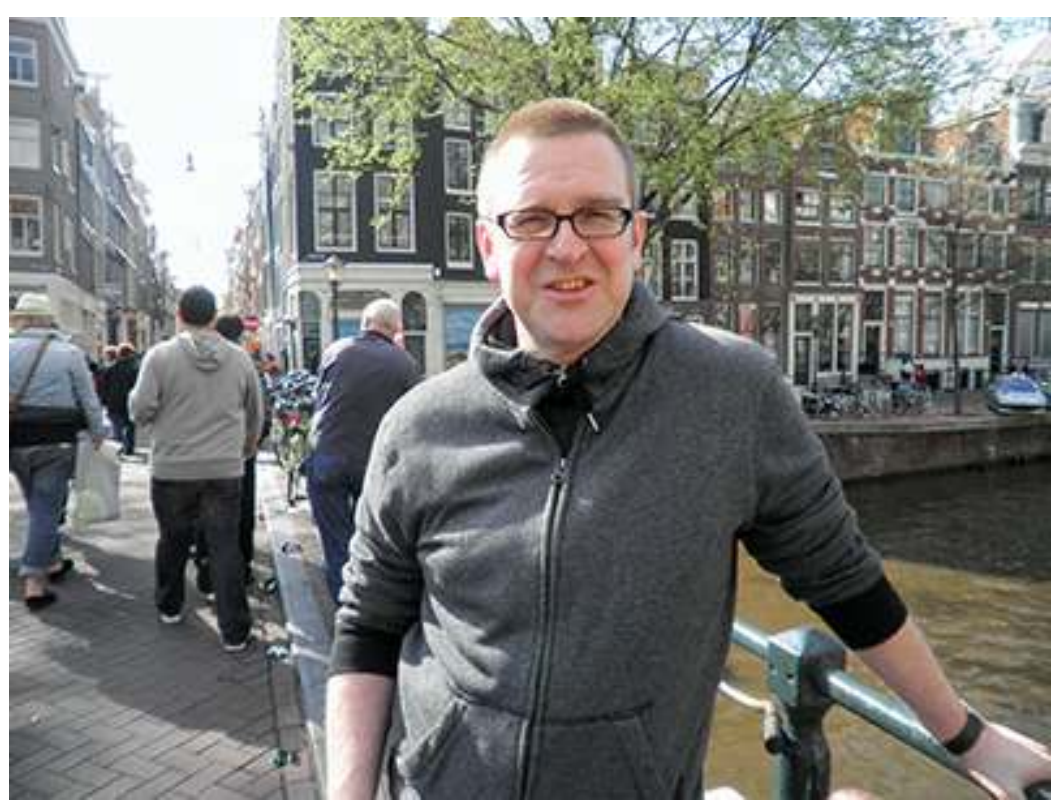

Olaf Stiegliz is a professor of American Cultural History at the University of Leipzig, Germany. His scholarship focuses mainly on the history of gender and the body, with a particular focus on embodiment in sport from the 1890s to the 1940s. His main publications include a history of information and denunciation in the United States (Undercover: Die Kultur der Denunziation in den USA, Campus Verlag, 2013) that not only examines various high marks of the culture of information in American society-from the creation of the FBI, wartime periods, and the "war on terrorism," to anticommunism, sexuality, and political radicalism-but also the historiographic and theoretical questions that the subject raises, in a largely Foucauldian-influenced cultural studies context. With Jürgen Martschukat, he co-wrote a history of masculinities (Geschichte der Männlichkeiten, Campus Verlag, 2008), a concise, Germanlanguage synthesis that situates masculinities studies through the lens of parenting, sociability, and sexuality. Also with Jürgen Martschukat, he co-edited a German- 
language, encyclopedic collection of essays on the intersection of the constructions race and sex in a variety of times and places-including slavery, colonialism, and genocides-through the study of major theorizations, conceptualizations, and representations, from Fanon, Du Bois, and Baldwin, Foucault, Butler, and Sedgwick, to western movies, Spike Lee's cinema, and jazz, or the dispossession of indigenous peoples in North and Central America, slavery in the Americas and the Caribbean, and the rise of eugenics and antisemitism in postcolonial Central Europe since the 1920s (Race \& Sex: Eine Geschichte der Neuzeit, Neofelis Verlag, 2016). His recent publications about sport examine a wide range of topics-e.g., the construction of modern female bodies in the early twentieth century, representations of sport in visual culture, the promotion of eugenics through fitness culture-through a variety of sports, mainly swimming, soccer, and track and field. Among the specificities of Stieglitz's scholarship are: an emphasis on the bodily dimension of the cultural constructions of masculinity, femininity, and gender; attentiveness to the intersection between the constructions of gender and race; and a critical reliance on visual culture as a historical source. These concerns have been present in his research since his first book on the construction of masculinity in the Civilian Conservation Corps (100 Percent American Boys: Disziplinierungsdiskurse und Ideologie im Civilian Conservation Corps, 1933-1942, Franz Steiner Verlag, 1999).

GUILLAUME MARCHE: Thank you very much for accepting this interview. It's very important for us to hear your thoughts on American studies as a fellow European from a country other than France. As a scholar based in Germany, how do you see the evolution of the field of American studies within your country's academic system and tradition? What does American studies mean to you: do you consider yourself primarily an American studies scholar, a cultural, social historian, or a cultural studies scholar who happens to focus on the United States...?

Olaf Stieglitz: More than 20 years ago now, I started out as a social historian and found myself in a German American studies community a) dominated by literary studies and b) by the heritage of a Cold War pattern that at that point still shaped much of the research both in history and in American studies in general. Against the backdrop of that starting point, the situation is very different now: I am still a historian, but I am teaching and researching in an American studies environment that is much more heterogeneous when it comes to topics, approaches, and perspectives. Doing cultural history of North America / the US puts me in an intermediate situation between the academic fields of history and American studies that I experience as enriching.

G.M.: Is there a big divide between these two disciplinary fields in Germany; I mean, do you find your situation as an intermediate between the two disciplines unusual, or are there a great many interactions between them? And if so, do you see the two as being on an even playing field, or do you find American studies more welcoming to the input of history, or the reverse?

O.S.: The situation had been rather difficult in the past but the degree of interaction between the two fields has increased largely over the last couple of years. "History" is now much more open to ideas and influences of cultural studies; and "American studies" is no longer that much dominated by literary studies. The cultural turns of the 1990 s have certainly changed how fields that were traditionally separated now interact with each other. Or at least, it opened a window for trying. 
G.M.: What part do American studies or other social science journals in Germany play in defining or challenging these disciplinary boundaries?

O.S.: Amerikastudien / American Studies, the official journal of the German Association of American Studies (Deutsche Gesellschaft für Amerikastudien, DGfA), does a good job in offering an interdisciplinary platform, and the editors of individual issues often encourage contributions from the margins of the field. The results are sometimes convincing, sometimes not; generally the trend towards a more open concept of what constitutes American studies is promising.

G.M.: What is the place of e-publishing a) in your country's academic system and tradition and b) in your own sub-field(s) of American studies? Does format (e-journal vs. print) matter a lot in the recognition of academic publications, or do e-journals enjoy just the same amount of recognition as printed journals?

O.S.: E-publishing has increased its visibility much over the last years; it is now an accepted thing to do, both to edit an online journal as well as to publish in one. Reputation, though, is a rather "conservative" currency-it takes a while for a new journal to get first accepted and then respected, but that was already true in the world of print. In my view, it is not so much the format that is responsible for a journal's reputation but its visibility; and visibility is a) a matter of tradition, and comes b) with good editing and interesting approaches.

G.M.: I am also wondering whether, or how deeply, the American studies publishing field in Germany is structured by the DGfA: are the main American studies journals-whether online or print-published under the aegis of the DGfA, or independently from it? Do you find that it hinders or fosters the reputation of American studies journals and, more generally, creativity in American studies scholarship?

O.S.: The publishing field of American studies is very much structured by the DGfA, and I am rather glad it is. I am quite certain that research in American studies would be less visible without that influence. As a historian, I can strategically decide whether I publish the results of my work in one field or the other-or in both, with different emphases respectively.

G.M.: Is peer-review the ultimate measure of a publication's worth, or do you see an evolution in practices or attitudes vis-à-vis peer-review: i.e., do you see other forms of scholarly publications than state-of-the-art, peer-reviewed articles as gaining recognition and legitimacy in American studies in Germany-or in academia in Germany in general?

O.S.: I am all in favor of peer-review, although I realize that the system puts a heavy burden on reviewers and is abused by university managements to quantify research that should not be quantified. I consider smaller, more open formats such as blogs or podcasts to be rising in recognition and relevance; they are welcomed opportunities for bridging the gap between academic research and a somewhat broader audience, for developing and experimenting with ideas before framing them in a cutting-edge article. Online journals should be open to such newer forms, should encourage them.

G.M.: As a social historian, do you find these halfway formats more relevant for very contemporary issues than more historiographic debates for example? Part of the background for this question is that Transatlantica in the past few years has published nonpeer-reviewed essays and debates on the history of slavery in film (on the occasion of the released of Nate Parker's The Birth of a Nation), or the conflicting memories of the Civil War (that was triggered by the publication of a heavily biased issue of a non-academic, yet somewhat highbrow magazine issue on the subject in 2017-2018, when the question of confederate monuments was a highly volatile topic before and after the 2016 presidential election). So it's not as if reaching broader audiences only pertained to current issues, 
although a larger public may be more curious about, and attuned to, questions that make the news. What's your take on that?

O.S.: You certainly raise an important and increasingly relevant point here. Memory studies and dealing with the role of history within contemporary political, social, and cultural debates became ever more important over the last years. Film, material culture, museums, memorials, etc.-studying these sources and how they connect past and present is immensely important in bridging the gap between academia and the public, and also for teaching. And yes, different formats can help us do that job, from film reviews in popular magazines to blog entries in non- or semi-academic websites.

G.M.: How do you feel about the academic and societal implications of publishing an academic journal?

O.S.: Publishing in an academic journal has become the gold standard, especially for those early in their careers. I am rather critical of that development, for several reasons: the burden is really high during times when focused research should be key, university managements and grant-offering institutions used that as a means to introduce a system of quantification inappropriate for the humanities, and it unnecessarily sidelines other forms of publications; e.g. books.

G.M.: Yes, that is part of a general managerial trend where the humanities and social sciences are treated according to standards that originated in the "hard" sciences-as well, perhaps, as law-and are often inappropriate or can prove detrimental to disciplinary fields where you simply need more time to provide worthwhile results. Not to mention the multiplication of non-scholarly tasks that we are increasingly swamped with... But we are all caught in this Faustian dilemma where great funding can be available if you meet these standards, so how much of your soul are you prepared to sell for that? I'm afraid this is less a question than just me ranting, but l'd be happy to read your thoughts on this.

O.S.: Well, in a way being a full professor makes the situation somewhat easier than for younger colleagues without permanent positions; at least I can decide for myself how hard I push on the treadmill.

G.M.: As to the societal implications of publishing an academic journal, in your experience as a scholar and a member of various scholarly associations and editorial boards, in Germany and abroad, do you find that that's an increasing concern in the profession, or is the academic field of American studies in Germany pretty much enclosed in an ivory tower?

O.S.: The trend is clearly to become more part of ongoing non-academic discourse, although not everybody is embracing this tendency. The reasons are complex-some respond to the pressure to justify American studies research in public against the backdrop of institutional cutbacks; others favor a more direct political motivation for intervention. American studies have a lot to offer here, and more and more colleagues are willing to speak up in public.

G.M.: How do you view current debates on the decolonization of academic research and curriculum? Do you consider academic research and teaching can, or should, have political implications in this respect? And do you see American studies as a particularly good place to address these issues-again, in the context of your country's academic system and tradition?

O.S.: In the German context, American studies have a very important role in introducing postcolonial thoughts into academic discourse and into the curriculum. Debates about decentering / provincializing America have been part of American studies for some time now, while history and cultural studies in Germany still 
struggle to address such questions. In my view, American studies scholars have much to contribute to that growing debate, whether one personally is in favor of such trends or more reluctant towards them.

G.M.: As you are probably aware, anything to do with race, ethnicity, or diversity is often disqualified as "American multiculturalism," as opposed to allegedly color-blind French "universalism." Arguably, this has a lot to do with France's unresolved colonial past. Considering Germany's different colonial history-perhaps less deeply engrained, largely repressed, though fundamentally structuring, as France's-, do you suppose it's an easier, less inflammatory issue to explore? Or is the alleged "foreignness" of such debates just as emphasized in Germany?

O.S.: This debate is currently gaining momentum in Germany. Germany has a colonial past as well, maybe not as long as Great Britain, France, or other countries, but certainly as violent and exploitative. This has been ignored, or marginalized, for a long time and now hits the public strongly. Postcolonialism has reached German academia as well as the German public, but it sometimes clashes painfully with other elements of history and memory politics, e.g. the centrality of the Holocaust for German memory politics. From the perspective of an Americanist, or historian of North America, this is a super interesting development because right now many elements of the American culture wars reappear in German discourse, and I think that the ongoing debates can profit from Americanists' voices sharing their perspectives.

G.M.: Thank you very much, Olaf, for accepting to share your experiences and insights on these issues.

\section{AUTHORS}

\section{GUILLAUME MARCHE}

Université Paris-Est Créteil

\section{OLAF STIEGLITZ}

Universität Leipzig 